\title{
ナノ濾過膜を用いた高温海水からのスケール成分除去
}

\author{
高羽洋充・布施正憲 $*$ 石川 徹 ${ }^{*} \cdot$ 木村尚史 ${ }^{*} \cdot$ 中尾真一 \\ 東京大学大学院工学系研究科化学システム工学専攻 函 113-8656 文京区本郷 7-3-1 \\ *工学院大学工学部環境化学工学科 函 163-8677 新宿区西新宿 1-24-2
}

\section{Removal of Scale-forming Components in Hot-seawater by Nanofiltration Membranes}

\author{
Hiromitsu Takaba, Masanori Fuse*, Touru Ishikawa*, Shoji Kimura*, \\ Shin-ichi Nakao
}

Department of Chemical System Engineering, School of Engineering, The University of Tokyo, Hongo, Bunkyo-ku, Tokyo 113-8656, Japan.

"Department of Environmental Chemical Engineering, Faculty of Engineering, Kogakuin University, 1-24-2 Nishi-shinjuku, Shinjuku-ku, Tokyo 163-8677, Japan

\begin{abstract}
Hot-seawater desalination process is much attractive as a novel cost-efficiency process to produce potable water. In the hot-seawater desalination process it is required to remove the scale-forming components in seawater before proceeding to the reverse osmosis membrane in order to prevent the scale forming on the membrane which results in deducing flux. In this study, we proposed that the nanofiltration membrane could be applied to the pretreatment process to remove the scale-forming components in hot-seawater desalination process. The rejection of scale-forming components in seawater on different commercial nanofiltration membranes as well as the temperature dependency of flux, rejection and effective charge density of the membrane was investigated. It was found that a certain nanofiltration membrane showed high rejection for sulfated ion while low rejection for calcium ion in the range of the temperature from $30^{\circ} \mathrm{C}$ to $50{ }^{\circ} \mathrm{C}$. An effective charge density of investigated nanofiltration membranes were at almost constant or slightly decreased in the range of $30{ }^{\circ} \mathrm{C}-50{ }^{\circ} \mathrm{C}$. Those results mean the possibility of the application of nanofiltration for the scale removal in the hot-seawater desalination process.
\end{abstract}

Keywords : nanofiltration membrane / hot seawater / scale / removal / desalination

\section{1. 緒言}

海水淡水化技術の 1 つである逆浸透法はエネル ギー消費量が蒸発法と比べて $1 / 4$ 程度という低コ ストであり，経済的に優れているのが特徴であ る $^{1-2)}$. そのため石油輸入国である日本ではその 恩恵が特に大きく, 沖縄や福岡で大規模な逆浸透
法海水淡水化プロセスが設置あるいは計画されて いる。しかしながら，その造水コストは淡水を原 料とする浄水コストと比べれば 2 倍以上であり, 一層のコスト削減が求められている．現在の逆浸 透法海水淡水化技術では, 海水の濃縮に伴う浸透 圧の増加が問題となって淡水の回収率は $40 \%$ 程 度であり，前処理にかなりのコストがかかってい 
ることを考慮するとエネルギー的な無䭾が大き い.そのため, 常圧と高圧を組み合わせた 2 段プ ロセスにすることによって，回収率を向上させ， 造水コストを削減する試みが最近行われている ${ }^{32}$. しかしながら，このような回収率向上策では，よ り高圧での運転が必要となるため，造水コストの 大幅な削減は難しいといえる。

そこで高羽・中尾は，高温海水を利用した高回 収率逆浸透法プロセスを提案している ${ }^{4)}$. 従来, 常温の海水を用いていた逆浸透プロセスに，高温 海水を用いることによって, 透過流束の増大, 所 要膜面積の大幅な削減が期待できる。 その結果, より低コストで造水を行うことが可能となる。モ デル計算では，海水予熱のための熱源が確保でき る場合には，造水コストを従来の 6 割以下に抑え ることが可能であることが示された。また，高温 海水を利用したプロセスには，その他にもいくつ かの長所がある. 例えば, 高温殺菌効果によって, 膜性能低下の原因となるバイオファウリングの抑 制効果が期待できる，さらには，得られる温淡水 を風呂や暖房用などの高温水用途として二次利用 することで，エネルギー効率のよい複合プロセス を構築できる可能性がある，また，高温淡水の粘 度は常温水と比べて低いので, 送水コストの低減 も期待される。

しかしながら，高回収率化に伴う一般的な問題 として，膜面でのスケール生成がある．スケール とは，濃度分極現象あるいは濃縮効果によって阻 止されたカルシウム等の膜面濃度が上昇し, それ らの一部が過飽和濃度となって膜面に析出するこ とであり，透過流束の減少を引き起こし逆浸透膜 の性能を低下させる.高温海水を用いた場合でも, $60 \%$ 以上の高回収率では膜面でのスケールの生 成が予想される。そのため，逆浸透膜処理の前に 何らかのスケール成分除去プロセスが必要とな る.

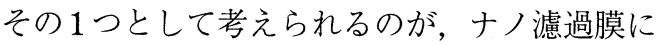
よる前処理プロセスである。ナノ滤過膜は荷電効 果によって 1 価， 2 価イオン選択性が期待でき， スケール成分の除去が可能だと考えられる ${ }^{5}$. 海 水中から生成すると考えられるスケール成分は,
$\mathrm{CaCO}_{3}, \mathrm{Mg}(\mathrm{OH})_{2}, \mathrm{MgCO}_{3}, \mathrm{CaSO}_{4}$ などである が，前者 3 つの成分については， $\mathrm{pH}$ を調整する ことで析出を防げるので，実際上問題となるのは $\mathrm{CaSO}_{4}$ である。 そのため, スケール成分除去に用 いるナノ濾過膜では，カルシウムイオン，あるい は硫酸イオンのどちらか一方を阻止する性能が求 められる.

これまでDow Chemical社のナノ濾過膜を用 いて海水中から硫酸イオンを除去するプロセスが 提案されている ${ }^{6,7)}$.また，都留 ${ }^{8)} \cdot$ 浦入 ${ }^{5} ら$ ら日 東電工社製の NTR-7450, NTR-7410膜を用いた 1 価, 2 価イオン選択性についての検討を行って いる.これらの研究によれば, マイナス荷電のナ ノ濾過膜によって硫酸イオンの高い阻止性能が期 待できることがわかる. 最近 Hassan ら ${ }^{99}$ は, 海 水からのスケール成分除去を目的としていくつか のナノ滤過膜の性能評価を行っている。しかしな がら, 単成分系と多成分系での阻止性能の比較, スケール除去性能の温度依存性についての報告例 はない。

そこで本研究では, 高温淡水化プロセスの前処 理プロセスとしてのナノ滤過膜適用の可能性を明 らかにするために，いくつかのポリスルホン系， ポリアミド系の市販ナノ濾過膜を用いて，海水中 に含まれるイオン種の，単成分，多成分系（人工 海水）における透過特性およびそれらの温度依存 性について検討を行った.

\section{2. 膜の性能評価}

ナノ濾過膜の透過特性の評価は, 濃度分極効果 を考慮した膜透過理論”に基づいて行った.

膜の性能は体積流束 $J_{v}$ と, みかけの阻止率 $\left(R_{o b s}=1-C_{p} / C_{b}\right.$, ただし $C_{p}$ は透過液濃度, $C_{b}$ は供 給液濃度）によって表すことができる。しかしな がら, 通常の膜分離では濃度分極現象が起こって いるので, 膜面での溶質濃度 $C_{m}$ を基準にした真 の阻止率 $R$ が用いられることが多い. 次式にその 定義を示す.

$$
R=1-\frac{C_{p}}{C_{m}}
$$


この $C_{m}$ を実測することは困難なので, 濃度分極 式と呼ばれる次式を用いて求める.

$$
\frac{C_{m}-C_{p}}{C_{b}-C_{b}}=\exp \left(\frac{J_{v}}{k}\right)
$$

$k$ は濃度分極層内の溶質の物質移動係数である.

$J_{v}$ および $R$ は操作条件によって変化するため, これを定量的に評価するためには様々な条件下で の結果を一般化して整理する必要がある.そこで, 次式で定義される膜固有のパラメータ $P$ および $\sigma$ を導入する (Speigler-Kedem 式).

$$
\begin{aligned}
& R=\frac{(1-F) \sigma}{(1-\sigma F)} \\
& \mathrm{F}=\exp \left\{\frac{-J_{v}(1-\sigma)}{P}\right\}
\end{aligned}
$$

ここで， $\sigma$ は溶質反射係数， $P$ は溶質透過係数で, $J_{v}$ が無限大のとき $R=\sigma$ とみなせる．そこで圧力 を変えて阻止率を測定し, 得られたデー夕を $R$ 対 $1 / J_{v}$ でプロットし, 式 (3) (4) をカーブフィテ イングすることによって $\sigma, P$ を求める.

一方, ナノ滤過膜では, 膜の荷電によってイオ ンを分離していると考えられるため, 膜の有効荷 電密度か膜性能の指標となる。荷電特性の評価に ついてはいくつかの理論が提案されているが, 本 研究では, 拡張されたネルンスト・プランク式と ドナン平衡式を組み合わせたTMS モデル ${ }^{8,10,11}$ を 用いた。TMSモデルにおいては, 膜は一定の荷 電密度を有する高分子の鎖構造が一様に分布して いる構造を仮定する。このモデルから, 荷電膜の 電解質阻止に関する $\sigma$ の值を以下の式で与えるこ とができる ${ }^{8,10)}$.

2-1 型溶質 $\left(\mathrm{CaCl}_{2}\right)$ の場合：

$$
\sigma=1-\frac{c_{+} c_{-}}{\left(c_{-}+t \phi X\right) C}
$$

ただし

$$
t=\frac{2 u_{+}}{2 u_{+}+u_{-}}
$$

また（5）式の $c_{-}, c_{+}$は以下の多項式を満たすも のとする。

$$
\begin{aligned}
& 4 c_{+}{ }^{3}-4 \phi X c_{+}{ }^{2}+\phi X^{2} c_{+}-4 C^{3}=0 \\
& c_{-}{ }^{3}+\phi X c_{-}{ }^{2}-8 C^{3}=0
\end{aligned}
$$

1-2 型溶質 $\left(\mathrm{Na}_{2} \mathrm{SO}_{4}\right)$ の場合：

$$
\sigma=1-\frac{c_{+} c_{-}}{\left(2 c_{-}+t \phi X\right) C}
$$

ただし

$$
t=\frac{u_{+}}{u_{+}+2 u_{-}}
$$

また（8）式の $c_{-}, c_{+}$は以下の多項式を満たすも のとする.

$$
\begin{aligned}
& c_{+}{ }^{3}-\phi X c_{+}{ }^{2}+\phi X^{2} c_{+}-8 C^{3}=0 \\
& 4 c_{-}{ }^{3}+4 \phi X c_{-}{ }^{2}+\phi X^{2} c_{-}-4 c^{3}=0
\end{aligned}
$$

ここで, $c_{-}, c_{+}$は膜中のイオン濃度, $\phi X$ は膜の 有効荷電密度, $C$ は供給液溶質濃度, $u_{+}, u_{-}$はイ オンの移動度を表す。

（5）または（8）式と実験結果から求められた $\sigma$ を比較することで, ナノ濾過膜の有効荷電密度 を見積もった。

\section{3. 実 験}

市販のナノ滤過膜（Table 1）と日東電工社製 の平膜用流通式テストセルを用い, 単成分 $\left(\mathrm{Na}_{2} \mathrm{SO}_{4}, \mathrm{CaCl}_{2}\right)$ ，および多成分 (人工海水) の 透過実験を行った. Table 2 には, 実験に用いた 人工海水の成分表を示した。 また実験装置のフロ ーシートをFig. 1 に示した。供給液温度は $30^{\circ} \mathrm{C}$, あるいは $40{ }^{\circ} \mathrm{C}, 50{ }^{\circ} \mathrm{C}$ に設定し，操作圧力は 1.0 $\mathrm{MPa}, 1.2 \mathrm{MPa}, 1.5 \mathrm{MPa}, 1.7 \mathrm{MPa}, 2.0 \mathrm{MPa}$ で実験を行い, 体積透過流束, および透過側溶質 濃度を測定した。透過側溶質濃度の測定には, 単 成分系については電気伝導度計を, 多成分系につ いてはICP 発光分析器あるいはイオンクロマト グラフィーを用いた. 供給液の流速は $4 \mathrm{l} / \mathrm{min}$ と した。このときの各溶質の物質移動係数を Table 3 に示す。各温度での物質移動係数は, $25^{\circ} \mathrm{Cにお}$ ける実測値を，(11）式に示す推算式年を用いて 温度補正したものである。

$$
k \propto T^{0.75^{*}} \rho^{0.625} / \mu^{1.375}
$$

\section{4. 結果と考察}

\section{1 単成分系の透過特性}

まず，スケール成分となる硫酸イオンおよびカ 
Table 1 The list of nanofiltraiton membranes used.

\begin{tabular}{lccc}
\hline & Membrane & Material & $\mathrm{NaCl}$ rejection \\
\hline Nitto Co. Ltd. & NTR-7410 & sulfated polyether sulfone & $10 \%\left(\mathrm{NaCl} 0.2 \%, 1.5 \mathrm{MPa}, 25{ }^{\circ} \mathrm{C}\right)$ \\
& NTR-7450 & sulfated polyether sulfone & $50 \%\left(\mathrm{NaCl} 0.2 \%, 1.5 \mathrm{MPa}, 25{ }^{\circ} \mathrm{C}\right)$ \\
& NTR-7250 & polyvinyl alcohol polyamide & $60 \%\left(\mathrm{NaCl} 0.2 \%, 1.5 \mathrm{MPa}, 25{ }^{\circ} \mathrm{C}\right)$ \\
& NTR-729HF polyvinyl alcohol polyamide & $93 \%\left(\mathrm{NaCl} 0.15 \%, 1.5 \mathrm{MPa}, 25{ }^{\circ} \mathrm{C}\right)$ \\
& ES-10 & aromatic polyamide & $99.5 \%\left(\mathrm{NaCl} 0.05 \%, 0.75 \mathrm{MPa}, 25{ }^{\circ} \mathrm{C}\right)$ \\
\hline Dow Chemical & NF-45 & composite membrane & $55 \%\left(\mathrm{NaCl} 0.2 \%, 0.91 \mathrm{MPa}, 25^{\circ} \mathrm{C}\right)$ \\
& NF-70 & composite membrane & $80 \%\left(\mathrm{NaCl} 0.2 \%, 0.49 \mathrm{MPa}, 25{ }^{\circ} \mathrm{C}\right)$ \\
\hline Toray Co. Ltd. & UTC-60 & polyamide & $55 \%\left(\mathrm{NaCl} 0.05 \%, 0.35 \mathrm{MPa}, 25{ }^{\circ} \mathrm{C}\right)$ \\
\hline
\end{tabular}

Table 2 The composition of the artificial seawater.

\begin{tabular}{cc}
\hline Ion species & Amount $[\mathrm{g} / \mathrm{l}]$ \\
\hline $\mathrm{NaCl}$ & 23.926 \\
$\mathrm{Na}_{2} \mathrm{SO}_{4}$ & 4.006 \\
$\mathrm{KCl}$ & 0.738 \\
$\mathrm{NaHCO}_{3}$ & 0.196 \\
$\mathrm{MgCl}_{2}\left[6 \mathrm{H}_{2} \mathrm{O}\right]$ & 10.831 \\
$\mathrm{CaCl}_{2}\left[2 \mathrm{H}_{2} \mathrm{O}\right]$ & 1.519 \\
\hline
\end{tabular}

Table 3 Mass transfer coefficient $k$

\begin{tabular}{ccc}
\hline $\begin{array}{c}\text { Temp. } \\
{\left[{ }^{\circ} \mathrm{C}\right]}\end{array}$ & $\begin{array}{c}k \mathrm{Na}_{2} \mathrm{SO}_{4} \\
{\left[\times 10^{-5} \mathrm{~m} / \mathrm{s}\right]}\end{array}$ & $\begin{array}{c}k \mathrm{CaCl}_{2} \\
{\left[\times 10^{-5} \mathrm{~m} / \mathrm{s}\right]}\end{array}$ \\
\hline 25 & 4.5 & 4.6 \\
30 & 5.3 & 5.4 \\
40 & 6.9 & 7.1 \\
50 & 8.8 & 9.0 \\
\hline
\end{tabular}

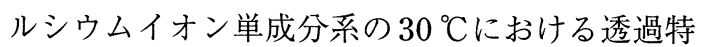
性について調べた，溶質にはそれぞれ硫酸ナトリ ウムと塩化カルシウムを用いた。硫酸ナトリウム の供給液濃度は, 海水中での硫酸イオン濃度の 2 倍 $\left(56 \mathrm{~mol} / \mathrm{m}^{3}\right)$ とした. Fig. 2 に, 実験から得 られた真の阻止率と体積透過流束の逆数 $\left(1 / J_{v}\right)$ の関係を示す. (3) (4) 式でカーブフィッティン グした結果も併せて示した. NTR-7410を除く 8 種類の膜については, 硫酸イオンに対して $R$ が 0.9 以上の高い阻止性能を示した。これは, これ らの膜がマイナス荷電であり, 膜の固定電荷と同 符号の硫酸イオンに対して静電的な反発が作用し たためだと考えられる。

Fig. 3 には，塩化カルシウムについての結果を 示した。供給液中の溶質濃度は海水中でのカルシ ウムイオン濃度の 2 倍 $\left(23 \mathrm{~mol} / \mathrm{m}^{3}, \mathrm{pH} 6.0\right)$ で

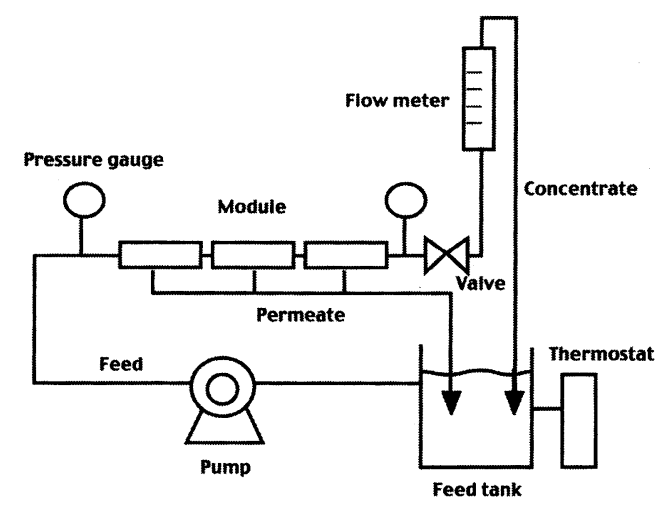

Fig. 1 Flow sheet of experimemtal apparatus.

ある. ほとんどのナノ濾過膜はカルシウムイオン に対しても比較的高い阻止率を示したが, NTR7450，NTR-7250，NTR-7410については 0.5 以 下であった. 高い阻止率を示した膜はいずれも分 画分子量が $200 \sim 600$ 程度と小さく, 分画分子量 が 1,000 程度の比較的ルーズな膜ではカルシウム イオンの阻止性能は低くなった。一方, 硫酸イオ ンの阻止性能については分画分子量との相関はみ られない.

スケール成分の除去プロセスに応用するために は, 硫酸イオンあるいはカルシウムイオンのどち らかを選択的に阻止することが望まれる。単成分 実験の結果からはNTR-7250あるいはNTR-7450 が両者のイオンに対して大きく異なる透過性を示 したことから，これらの膜がスケール成分の除去 に適しているといえる。 

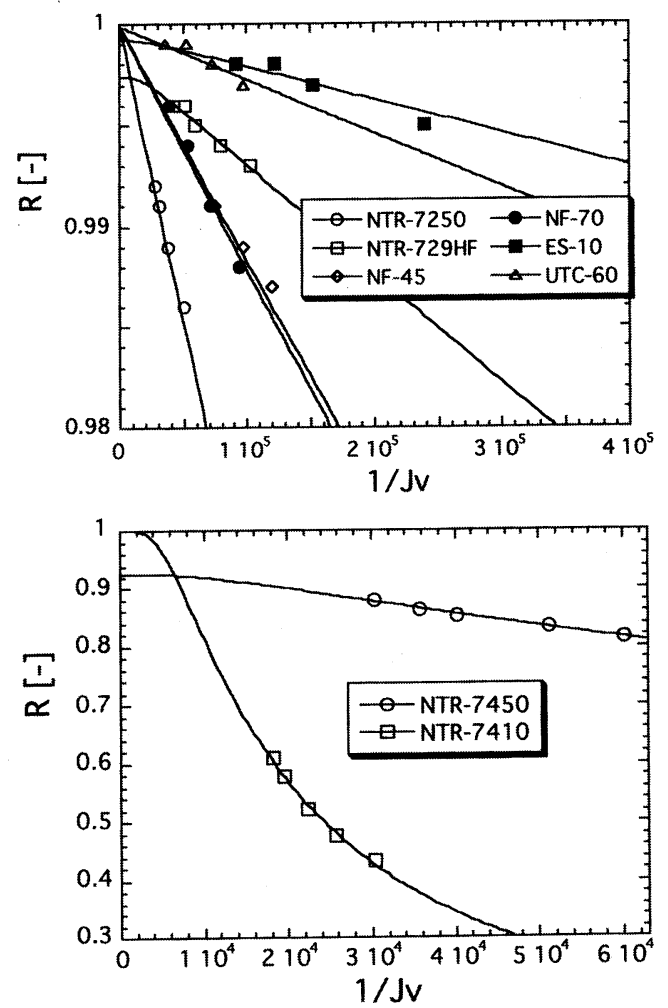

Fig. $2 R$ vs. $1 / J_{v}$ plot for a feed of $\mathrm{Na}_{2} \mathrm{SO}_{4}$ $56\left[\mathrm{~mol} / \mathrm{m}^{3}\right]$

\section{2 単成分系の反射係数および溶質透過係数 の温度依存性}

Fig. 4 には，硫酸ナトリウム溶質 $\left(56 \mathrm{~mol} / \mathrm{m}^{3}\right)$ について, 圧力に対する体積透過流束の温度依存 性を示した。なお温度依存性については, NTR7450, NTR-7250, NTR-729HF についてのみ検

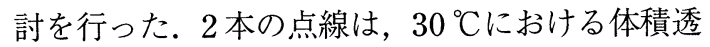

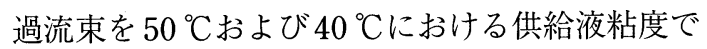
温度補正したものである.この図に示されるよう に, 体積透過流束の実測值は粘度で補正された值 よりも若干小さくなる傾向にある。これは, 温度 の上昇に伴う膜の圧密化など, 何らかの構造変化 が膜に起きたことを示唆している，また，塩化力 ルシウム $\left(23 \mathrm{~mol} / \mathrm{m}^{3}\right)$ についも同様の検討を行 ったが傾向は同じであった。なお，NTR-7450に ついて $40{ }^{\circ} \mathrm{C}$ 值が $50{ }^{\circ} \mathrm{C}$ 值とほほ等しくなって いるがこの理由については不明である.

Fig. 5 は, 同様の系について, 真の阻止率と体
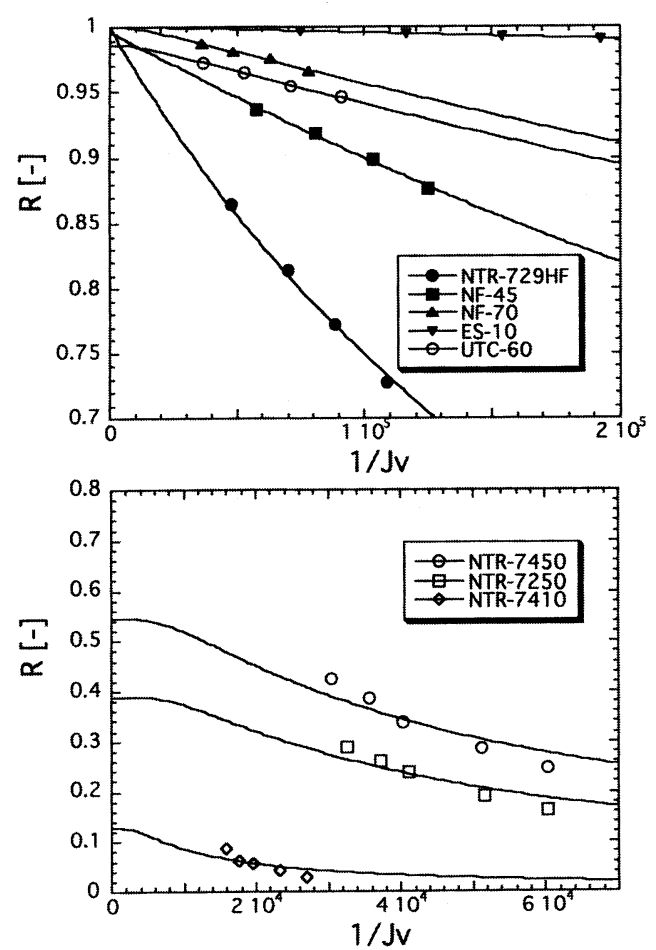

Fig. $3 R$ vs. $1 / J_{v}$ plot for a feed of $\mathrm{CaCl}_{2}$ $23\left[\mathrm{~mol} / \mathrm{m}^{3}\right]$

積透過流束の温度依存性を示したものである. 図 に示されるように, $1 / J_{v}=0$ の外挿から見積られる $\sigma$ の值は温度上昇に伴い減少しているが，阻止率 が高いものほどその温度依存性は小さくなってい る、温度上昇による阻止率低下には, 幾つかの要 因が考えられる。野村ら ${ }^{12)}$ は，ポリスルホン系の 限外濾過膜を用いてポリエチレングリコール（分 子量 504）の透過性の温度依存性を検討している. その結果, 温度上昇による真の阻止率の低下は, 主に溶質分子の運動性が活発になり膜を透過しや すくなることが原因であり, 溶質透過係数の増大 から判断できると報告している。 そこで, Fig. 5 のフィッティング結果から求められた溶質透過係 数 $P$ の温度依存性を Fig. 6 に示した. 我々の系で は，Pは温度によらずほぼ一定であることが示さ れている。このことは, 温度上昇によって溶質の 運動性が活発になるものの, 圧密化など透過を抑 制する他の要因が存在することを示唆している. 野村らの実験では, 体積透過流束の温度依存性は, 
194 高羽・布施・石川 - 木村 · 中尾 : ナノ滤過膜を用いた高温海水からのスケール成分除去
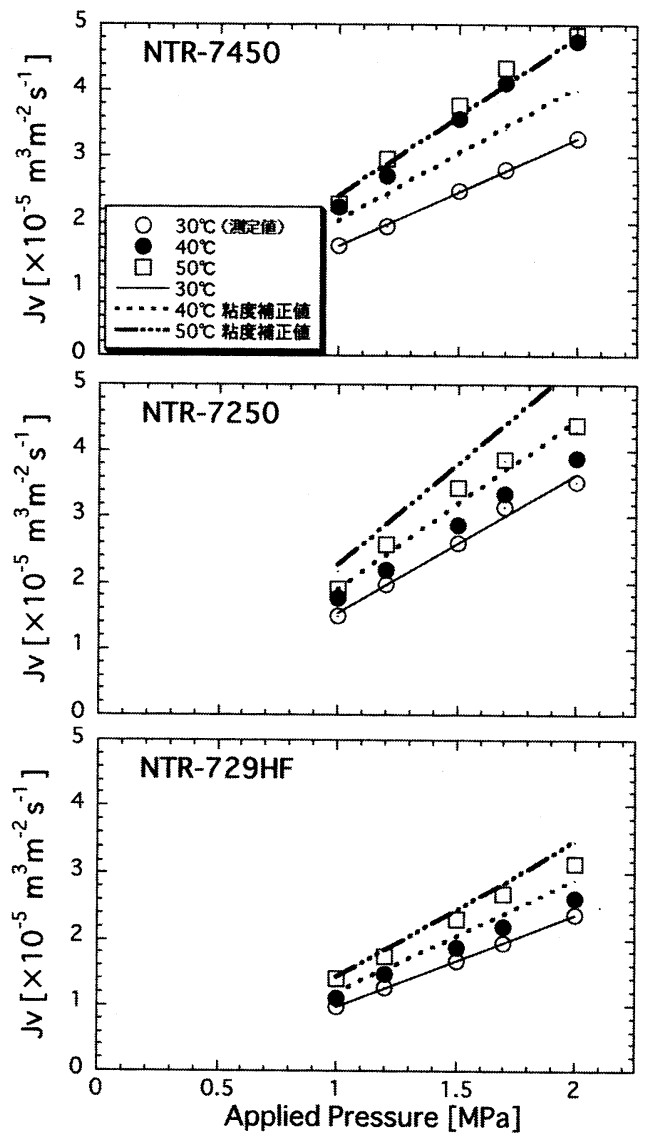

Fig. 4 Influence of the feed temperature on applied pressure vs.

$J_{v}$ plot for $\mathrm{Na}_{2} \mathrm{SO}_{4} 56\left[\mathrm{~mol} / \mathrm{m}^{3}\right]$. Broken lines are the corrected values using viscosity of feed : $J_{v}(\mathrm{t})=J_{v}\left(30{ }^{\circ} \mathrm{C}\right) \times \mu\left(30{ }^{\circ} \mathrm{C}\right) /$ $\mu(\mathrm{t})$.

供給液の粘度で温度補正した值よりも若干高くな る傾向にあった. しかしながら, Fig. 4 に示され るように我々が試した膜では逆の傾向が示されて おり，透過性に対する温度の影響は限外濾過膜と ナノ濾過とでは異なるといえる。

Fig. 7 には，(5) 式から求めた有効荷電密度の 温度依存性を示した。溶質は硫酸ナトリウム $(56$ $\mathrm{mol} / \mathrm{m}^{3}$ ) である. NTR-7450 と比較し, NTR7250 およびNTR-729HF は 2 倍以上の有効荷電 密度を持つことが示されている。また，阻止率が ほほ1に近かったNTR-729HF を除いて, 有効荷 電密度は温度によって若干減少する傾向にあるこ

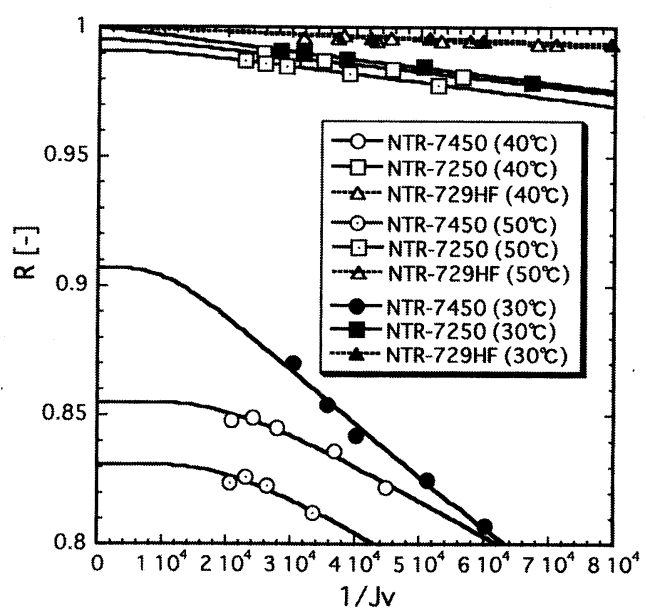

Fig. 5 Infuluence of the feed temperature on $\mathrm{R}$ vs.

$1 / J_{v}$ plot for $\mathrm{Na}_{2} \mathrm{SO}_{4} 56\left[\mathrm{~mol} / \mathrm{m}^{3}\right]$.

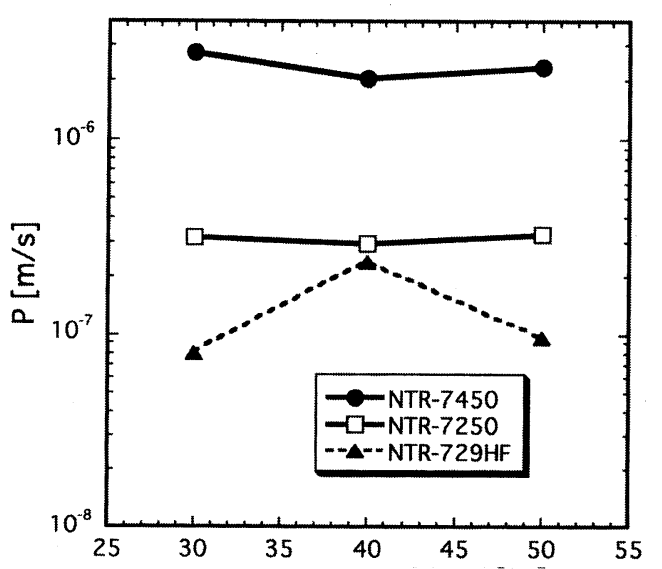

Fig. 6 Infuluence of the feed temperature on $P$ vs.

$1 / J_{v}$ plot for $\mathrm{Na}_{2} \mathrm{SO}_{4} 56\left[\mathrm{~mol} / \mathrm{m}^{3}\right]$.

とがわかる.ナノ濾過膜では荷電によって分離が 起こるため, 温度の上昇によって膜中の荷電基密 度が減少し，阻止率が減少したとも考えられる。 しかしながら荷電基密度の減少の理由, および構 造変化との相関についてはより詳細な検討が必要 である。

Fig. 8 には, 膜の有効荷電密度の濃度依存性を 示した．膜がNTR-7250の場合の結果である，有 効荷電密度の濃度依存性については, Wang ${ }^{13,14)}$ らによって次のような経験式が提案されている。 


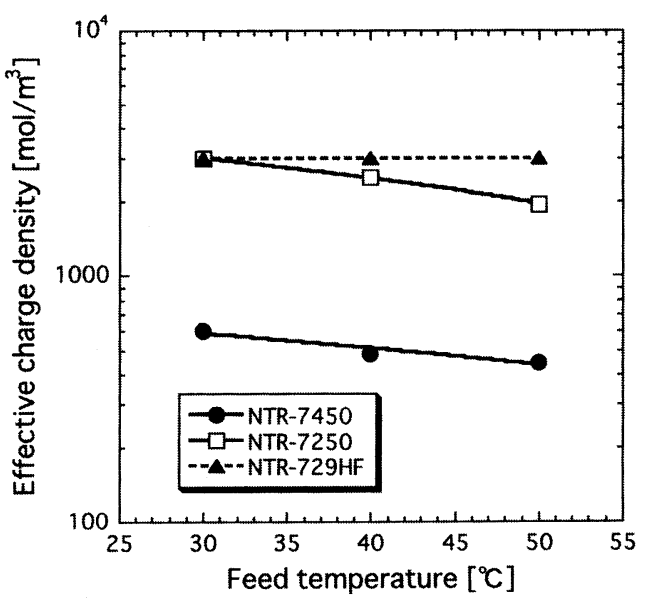

Fig. 7 Dependency of an effective charge density for $\mathrm{Na}_{2} \mathrm{SO}_{4} 56\left[\mathrm{~mol} / \mathrm{m}^{3}\right]$ on the temperature.
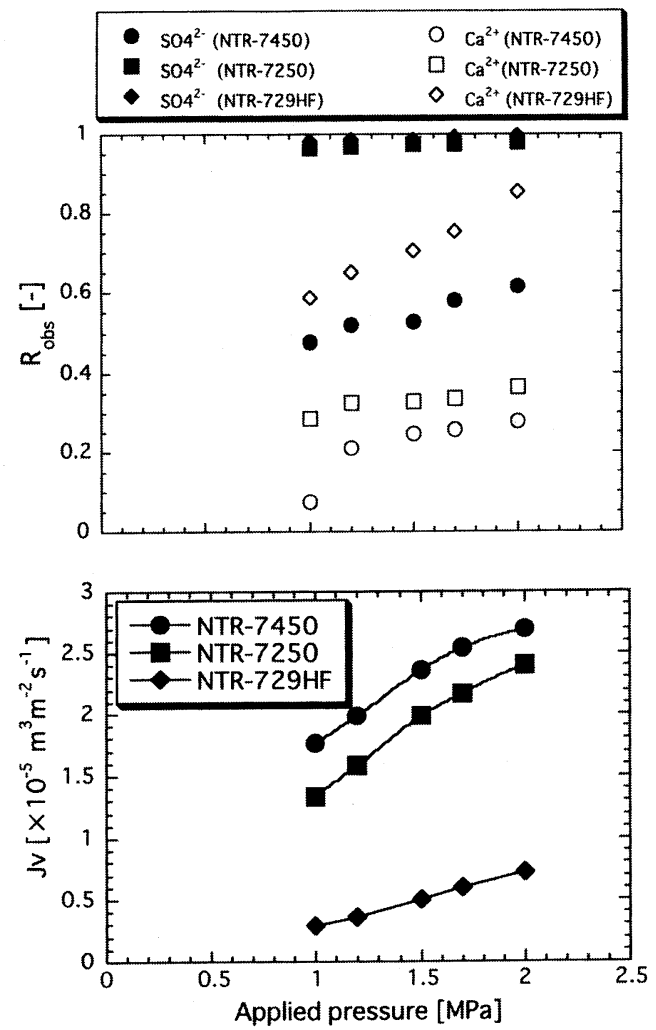

Fig. 9 Rejection and flux of $\mathrm{Ca}^{2+}$ and $\mathrm{SO}_{4}{ }^{2-}$ ions through different NF membranes in artificial seawater.

The temperature of feed is $30^{\circ} \mathrm{C}$.

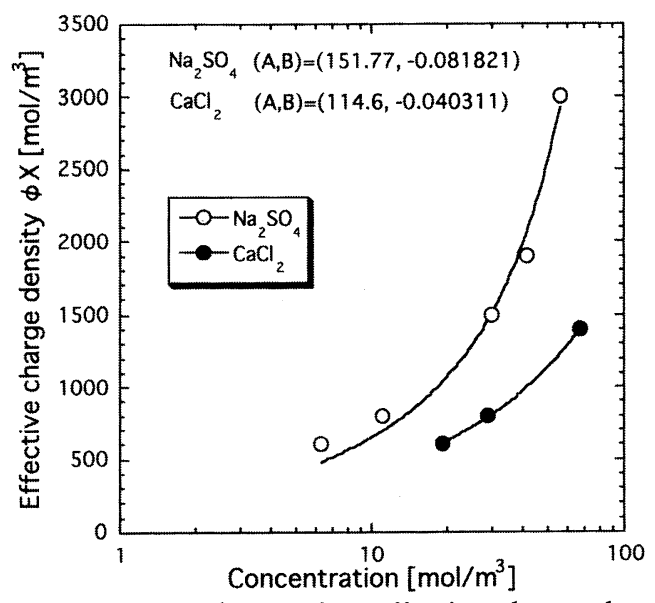

Fig. 8 Dependency of an effective charge density on the concentration.

Measured membrane is an NTR-7250. The temperature of feed is $30{ }^{\circ} \mathrm{C}$. Fitting curves are estimated by a theoretical equation (12). Estimated parameters for Equation (12), Namely A and B, are also presented.

$$
\phi X=\frac{A \sqrt{c}_{b}}{1+B \sqrt{c}_{b}}
$$

ここで $A, B$ がフィッティングパラメータである. 図にはこの式によるフィッティングの結果も示し てある．図に示されるように，有効荷電密度の濃 度依存性はこの経験式によってよく再現できるこ とがわかる.

\section{3 人工海水の透過特性}

人工海水を用いた場合の透過特性について調べ た．なおここでは，単成分の透過実験においてス ケール成分の選択透過が認められた, NTR-7450, NTR-7250，および比較のためにNTR-729HF の 3 種の膜についてのみ検討を行った. Fig. 9 は, 供給液温度が $30{ }^{\circ} \mathrm{C}$ のきの見かけの阻止率と透 過流束の圧力依存性を示したものである。硫酸イ オンおよびカルシウムイオンに対して，単成分の 時と同様の阻止性能が確認できた. Fig. 10 には, 同様の系について供給液温度 $50{ }^{\circ} \mathrm{C}$ のきの結果 を示した. Fig. 9 と比較し, 温度上昇によって見 かけの阻止率は全般的に低下する傾向を示した。 しかしながら，硫酸イオンに対しては依然として 
高羽・布施・石川・木村 ・ 中尾 : ナノ濾過膜を用いた高温海水からのスケール成分除去
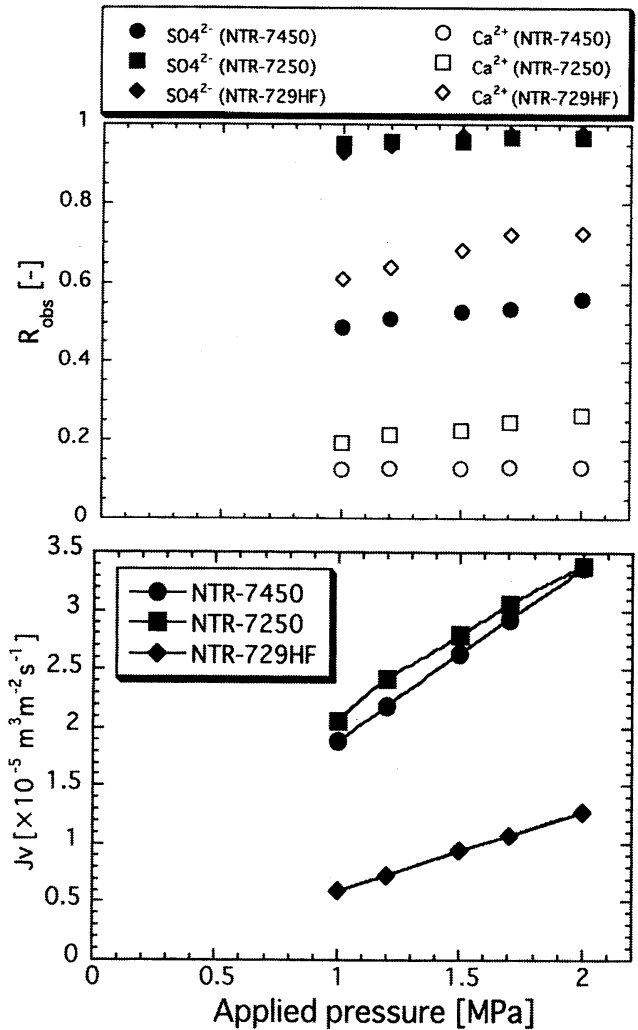

Fig. 10 Rejection and flux of $\mathrm{Ca}^{2+}$ and $\mathrm{SO}_{4}{ }^{2-}$ ions through different NF membranes in artificial seawater.

The temperature of feed is $50{ }^{\circ} \mathrm{C}$.

0.9 以上の高い阻止率を維持している。また，よ り阻止率の低いカルシウムイオンの方が温度上昇 に伴う阻止率の低下幅が大きい，従って，常温お よび高温の場合においてもこれらのナノ滤過膜に よるスケール成分の選択分離が可能であるといえ る．また，供給液の温度上昇による透過流量の増 加も確認された。

Fig. 11 には，NTR-7250による人工海水の実 験から求められた，各イオン種の見かけの阻止率 の測定結果を示した $\left(\right.$ 温度 $\left.50{ }^{\circ} \mathrm{C}\right)$. 硫酸イオンの 阻止性能が他のイオン種と比べて非常に高いこと がわかる。一方，1価のイオン種の阻止率は低く， カルシウムイオンを除けば 2 価イオンの阻止率が 高いことから 1 価， 2 価の分離が可能であること が示されている.

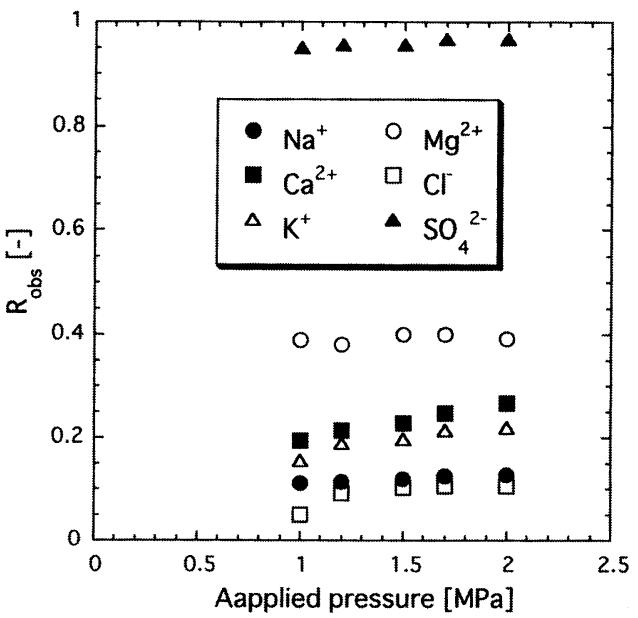

Fig. 11 Rejection and flux various ions through an NTR-7250 membrane in artificial seawater.

The temperature of feed is $50{ }^{\circ} \mathrm{C}$.

\section{5. 結 論}

本研究によって，ナノ濾過膜を用いて海水中の カルシウムイオンと硫酸イオンの分離が，常温お よび $50{ }^{\circ} \mathrm{C}$ 高温でも可能であることが示された. カルシウムイオンの透過率は $70 \%$ 以上であり, 一方硫酸イオンの透過率は $5 \%$ 未満であったこと から，ナノ滤過膜は海水淡水化におけるスケール 成分の除去に有効であるといえる。この場合，透 過液を逆浸透淡水化プロセスの供給液として用い るならば，80\%以上の回収率でもスケール生成 の心配はない.

しかしながら，ナノ濾過膜を前処理として用い た場合の全体での回収率は，ナノ濾過膜での回収 率と逆浸透膜での回収率の積となるため, ナノ滤 過膜での透過量をできるだけ多くしなければなら ない，造水コスト削減という面からは，現在前処 理として用いられている凝集沈殿, 砂濾過の代わ りにナノ濾過膜を利用する可能性についても検討 する必要があろう。

また，体積透過流束の温度変化は，透過液粘度 の温度依存性では説明はできず，温度上昇による 膜構造変化の可能性が示唆された。また，今回検 討したナノ滤過膜の有効荷電密度の值は, $30^{\circ} \mathrm{C}$ から $50{ }^{\circ} \mathrm{C}$ の温度範囲では，阻止率がほぼ 1 に近 


\begin{tabular}{|c|c|}
\hline \multicolumn{2}{|l|}{ 記号表 } \\
\hline$P$ : 溶質透過係数 & {$[\mathrm{m} / \mathrm{s}]$} \\
\hline$C_{m}:$ 膜面溶質濃度 & {$\left[\mathrm{mol} / \mathrm{m}^{3}\right]$} \\
\hline$C_{p}:$ 透過液溶質濃度 & {$\left[\mathrm{mol} / \mathrm{m}^{3}\right]$} \\
\hline$C_{b}$ : 供給液溶質濃度 & {$\left[\mathrm{mol} / \mathrm{m}^{3}\right]$} \\
\hline C : 供給液溶質濃度 & {$\left[\mathrm{mol} / \mathrm{m}^{3}\right]$} \\
\hline$J_{v}$ : 膜透過体積透過流束 & {$\left[\mathrm{m}^{3} /\left(\mathrm{m}^{2} \mathrm{~s}\right)\right]$} \\
\hline$k$ : 濃度分極層内での溶質の & 多動係数 $[\mathrm{m} / \mathrm{s}]$ \\
\hline$R$ : 真の阻止率 & {$[-]$} \\
\hline$R_{o b s}:$ 見かけの阻止率 & {$[-]$} \\
\hline$\sigma$ ：溶質反射係数 & {$[-]$} \\
\hline$u_{+}$: 陽イオンの移動度 & {$\left[\mathrm{m} \mathrm{m}^{2} /(\mathrm{Js})\right]$} \\
\hline$u_{-}$: 負イオンの移動度 & {$\left[\mathrm{m} \mathrm{m}^{2} /(\mathrm{Js})\right]$} \\
\hline$c_{+}$: 膜中での陽イオン濃度 & {$\left[\mathrm{mol} / \mathrm{m}^{3}\right]$} \\
\hline$c_{-}:$膜中での負イオン濃度 & {$\left[\mathrm{mol} / \mathrm{m}^{3}\right]$} \\
\hline$\phi X:$ 有効荷電密度 & {$\left[\mathrm{mol} / \mathrm{m}^{3}\right]$} \\
\hline$\mu$ : 粘度 & [Pa s] \\
\hline$\rho:$ 密度 & {$\left[\mathrm{kg} / \mathrm{m}^{3}\right]$} \\
\hline$T$ : 温度 & {$[\mathrm{K}]$} \\
\hline
\end{tabular}

い膜を除けば，若干減少する傾向を示した.

本研究では, $50{ }^{\circ} \mathrm{Cで}$ 透過実験を行ったが, 高 温淡水化プロセスでは $60{ }^{\circ} \mathrm{C}$ 程度での操作が効率 的だと考えられることから，より高温でも構造的 に安定で大きな透過流束を維持できるナノ濾過膜 の開発が望まれる。

\section{謝 辞}

本研究の一部は, 財ソルト・サイエンス研究財団
の平成 11 年度研究助成の一環, および財造水促進セ ンターの援助を受けて行われた。また，内容の一部 について議論をして頂いた広島大学の都留稔了先生 に感謝します。

\section{文献}

1）日本膜学会編：“膜分離プロセスの設計法”, 喜多 見書房 (1985)

2）木村尚史，中尾真一：“分離の技術一膜分離を中心 として”，大日本図書（1997）

3）山村弘之，木原正治，房岡良成，日本海水学会第 50 年会要旨集, p. 25, (1999)

4) 高羽洋充, 中尾真一：海水学会誌, 54, 37 (2000)

5) M. Urairi, T. Tsuru, S. Nakao, S. Kimura : $J$. Membrane Sci., 70, 153 (1992)

6) K. O'Donnell : Oil \& Gas J., Dec. 2, 58 (1996)

7) R. Davis, I. Lomax, M. Plummer : Oil \& Gas J., Nov. 25, 59 (1996)

8) T. Tsuru, S. Nakao, S. Kimura : J. Chem. Eng. Jpn., 24, 511 (1991)

9) A. M. Hassan, A. M. Farooque, A. T. M. Jamaluddin, A. S. Al-Amoudi, M. A. K. Al-Sofi, A. Rubian, M. M. Gurashi, N. M. Kither, A. G. I. Dalvi, I. A. R. Al-Tisan : San Diego Proceeding, II, 15 (1999)

10) I. Jitsuhara, S. Kimura : J. Chem. Eng. Jpn., 16, 389 (1983)

11) I. Jitsuhara, S. Kimura : J. Chem. Eng. Jpn., 16, 394 (1983)

12）野村剛志, 中尾真一, 木村尚史：化学工学論文集, 13, 811 (1987)

13) X. L. Wang, T. Tsuru, M. Togoh, S. Nakao, S. Kimura: J. Chem. Eng. Jpn., 28186 (1995)

14) X. L. Wang, T. Tsuru, S. Nakao, S. Kimura : J. Membrane Sci., 135, 19 (1997)

(受付 2000 年 4 月 24 日 修正稿受付 6 月 5 日 揭載決定 6 月 16 日） 